\title{
O contato com a natureza na história de vida e a formação de sujeitos ecológicos
}

\section{The Contact with Nature in Life History and the Construction of Ecological Subjects}

\author{
Zysman NEIMAN*
}

\begin{abstract}
RESUMO
Este artigo analisa a trajetória de vida e os momentos cruciais que influenciaram cinco profissionais a se dedicarem à área ambiental. Seus depoimentos foram colhidos por meio de entrevistas não direcionadas e contribuem para revelar algumas semelhanças que parecem ser relevantes para a compreensão de suas formações como sujeitos ecológicos: o contato direto com a natureza e o exemplo de outras pessoas ou organizações.
\end{abstract}

Palavras-chave: educação ambiental; história de vida; ambientalismo.

\begin{abstract}
This article examines the life course and the key moments that influenced five professionals to get involved with the environmental field. Their testimonies were collected through non-directed interviews, and contribute to reveal some similarities that seem to be relevant for the understanding of their development as ecological subjects: their direct contact with nature and the examples set by other people or organizations.
\end{abstract}

Key words: Environmental Education; Life History; Environmentalism.

\section{Introdução}

Kramer e Souza (1996), Minayo (1996), Thompson (1992) e Velho (1989), enfatizam o papel fundamental da história de vida nas investigações sociais, considerando-a como estratégia de compreensão de realidade, tendo sua aplicação vinculada a construções biográficas e autobiográficas de pessoas, grupos e instituições. Para Bosi (1994), o único modo correto de compreender uma história de vida é levar o sujeito a fazer a narração de sua autobiografia, $o$ testemunho mais eloquente dos modos que a pessoa tem de lembrar (p. 68).

As pesquisas que usam a história de vida como método objetivam propiciar um campo interpretativo dos fenômenos que rompa com a noção de um determinismo da História em relação às histórias, considerando que a valorização dos sujeitos - atores sociais - oferece um campo de investigação no qual a relação entre o individual e o social seja de reciprocidade e de interconstrução (TEIXEIRA, 2003).

\footnotetext{
" Doutor em Psicologia, Mestre em Psicologia, Bacharel e Licenciado em Ciências Biológicas. Professor Adjunto da Universidade Federal de São Carlos - UFSCar, Laboratório de Ecoturismo, Percepção e Educação Ambiental - LEPEA, Campus Sorocaba. Email: zysman@ufscar.br.
} 
Utilizar relatos numa tentativa de melhor compreender determinado fenômeno social é metodologia corriqueira nas ciências sociais e, com relação à questão ambiental, vem sendo utilizada por alguns autores, como Carvalho (2001) e Urban (2001).

Não se pode querer que os relatos, como em qualquer pesquisa qualitativa, revelem uma "exatidão" dos fatos. No entanto, para Bosi,

[...] ser inexato não invalida o testemunho. Diferentemente da mentira, muitas vezes exata e detalhista. Vivemos numa sociedade a quem foi roubado o domínio do tempo, marcada pela descontinuidade. A narrativa é sempre uma escavação original do indivíduo, em tensão constante contra o tempo organizado pelo sistema. Esse tempo original e interior é a maior riqueza de que dispomos. Qual versão de um fato é a verdadeira? Nós estávamos e sempre estaremos ausentes dele. Não temos, pois, o direito de refutar um fato contado pelo memorialista, como se ele estivesse no banco dos réus para dizer a verdade, somente a verdade. Ele, como todos nós, conta a sua verdade (2003, p. 65-66).

Velho (1989) acredita que a narrativa de histórias de vida ("pesquisa-diálogo") é um método privilegiado de acesso às experiências e às dificuldades vividas por uma pessoa e ao modo como ela interpreta sua experiência frente a um outro sujeito que, investido da função de "pesquisador-autor", participa ativamente da construção da narrativa. $\mathrm{O}$ autor propõe um trabalho de pesquisa que considere a interferência emocional do pesquisador, ressaltando que sua marca não se coloca somente no momento da entrevista propriamente dita, mas a antecede e é continuada com o trabalho de organização e interpretação dos dados.

No que se refere à questão ambiental, Carvalho (2001, p. 30-31) afirma que

[...] uma maneira produtiva de compreender a experiência do educador ambiental seria tomá-lo como um intérprete de seu contexto, ao mesmo tempo em que é um sujeito interpretado. (...) Diferentemente de um sujeito-observador, situado fora do tempo histórico, perseguindo os sentidos verdadeiros, reais, permanentes e inequívocos, o sujeito-intérprete estaria diante de um mundo-texto, mergulhado na polissemia e na aventura de produzir sentido a partir de seu horizonte histórico.

A tradição ambiental constitui um território simbólico, uma trama de sentidos e temporalidades sempre reencontrados e recriados nos autoposicionamentos dos sujeitos em suas trajetórias de vida. O autorrelato, nesse sentido, é o locus desse encontro entre a vida íntima do indivíduo e sua inscrição numa história social e cultural (Ibid., p. 71).

Este artigo optou por analisar a trajetória de vida e os momentos cruciais que parecem ter influenciado cinco profissionais a se dedicarem à área ambiental. Os depoimentos foram colhidos de modo livre por meio de entrevistas não direcionadas, onde os atores foram convidados a relembrar sua história e tentar detectar nela os fatos marcantes que promoveram seu interesse pela questão ambiental. Seus depoimentos contribuem para revelar algumas semelhanças que nos parecem ser relevantes para a compreensão do surgimento desse interesse.

Segundo Bosi,

[...] quando se trata de história recente, feliz o pesquisador que se pode amparar em testemunhos vivos e reconstruir atitudes e sensibilidades de uma época! (p. 16-17) (...) Um "vol d'oiseau" sobre a evocação biográfica nos fará ver, como numa tapeçaria, um mosaico de áreas mais ou menos densas, mais ou menos ligadas, algumas abandonadas, outras cultivadas amorosamente. E pontos privilegiados, como torres ou marcos, focos de atração na paisagem (2003, p. 62).

São justamente alguns desses marcos que podem dar pistas sobre o processo de aproximação à temática ambiental de cada um.

Os entrevistados foram escolhidos porque são profissionais com pelo menos 10 anos de atuação no campo ambiental (no momento da entrevista) e seus trabalhos são reconhecidos pelos pares. Embora não se configurem como as principais lideranças do movimento, como no caso de Carvalho (2001) e Urban (2001), todos eles têm a sua história de vida diretamente atrelada ao movimento ambientalista, sendo, portanto, exemplaridade no que se refere às atitudes pró-ambiente. 


\section{Os entrevistados}

Rita Mendonça, Diretora do Instituto Romã de Vivências na Natureza e coordenadora do Programa "Caminhadas Ecológicas e Filosóficas”, da Associação Palas Athena, é autora de livros, dentre os quais, Como cuidar do seu meio ambiente, À sombra das árvores e Conservar e criar.

Em entrevista concedida no dia 26/06/2003, em São Paulo, revelou que passou sua infância em uma pequena cidade no interior de São Paulo, mas foi só no cursinho pré-vestibular que, por intermédio de um professor, teve pela primeira vez contato com os conceitos de "impactos na natureza" e "ecossistemas", e aquilo lhe pareceu completamente fascinante.

A convivência com um grande amigo lhe influenciou na decisão de cursar Biologia. Por intermédio de uma colega, que em 1975 estudava no Instituto de Biociências da USP, assistiu a algumas aulas como ouvinte, o que lhe deu a certeza de que deveria seguir o caminho da Biologia.

Mas depois que ingressou no curso, a Biologia foi lhe frustrando progressivamente. Na época Rita não tinha clareza, e só mais tarde (após vinte anos) veio a compreender que sua busca é entender por que, apesar de sabermos que estamos caminhando para a nossa destruição, somos impelidos a ser como somos?

A principal frustração de Rita é perceber que a Biologia faz pouca referência sobre a questão ambiental. Aquela disciplina que deveria ser o estudo da vida era apenas o estudo do suporte sobre o qual a vida se processa. A vida em si, para Rita, é assunto da Filosofia, e não da Biologia.

Ainda durante a faculdade, Rita morou em um sítio no município de São Roque (SP). Formada, decidiu fazer pós-graduação na França (com dissertação de mestrado sobre a Amazônia), onde se tornou amiga de pessoas muito combativas e atuantes na área ambiental. Após cinco anos, voltou para o Brasil e passou um período em João Pessoa (PB), onde trabalhou com pesquisa em Ecologia Humana. Regressou para São Paulo, onde passou a trabalhar numa empresa de engenharia, atuando na coordenação de estudos ambientais.

Anos mais tarde, foi trabalhar no Instituto Florestal (IF) com Unidades de Conservação do litoral sul do Estado de São Paulo. Lá se aproximou da questão da relação homem/natureza. Para Rita, a Estação Ecológica da
Jureia-Itatins era um lugar de muitos conflitos, mas lindo, maravilhoso, e durante seu trabalho na região procurou sensibilizar o próprio IF sobre a relevância da manutenção dos moradores na região.

Fez algumas consultorias na área ambiental e foi convidada a trabalhar no SENAC, na implantação do curso de Especialização em Turismo Ambiental (depois, Ecoturismo). Em 1994 viajou pela primeira vez aos Estados Unidos; foi quando conheceu os livros do Professor Joseph Cornell e teve clareza sobre em que, de fato, queria trabalhar. Na entrevista concedida a esse autor, Rita declarou a importância que aquele encontro teve para a sua escolha de trabalhar diretamente com grupos de pessoas visitando áreas naturais, revelando que, no seu caso, o exemplo de outras pessoas foi decisivo:

- Um dia fui visitar o WWF, olhei uma estante, vi o livro do Joseph Cornell e comecei a folhear... Aí, realmente, eu fui pirando... Acho que foram tantos anos de um desejo interno que eu não sabia identificar, de repente, nesse momento, veio tudo de uma vez... isso aqui é tudo o que eu quero, tem a minha cara. E isso foi reforçado por uma frase que ele escreve logo na introdução: Não se sinta mal se você não sabe nomes. Ele disse aquilo logo para mim, que me sentia na obrigação de saber o nome de tudo, e não sabia de nada... meia dúzia de coisas... se você sabe de plantas, não sabe de crustáceos, não sabe de mamíferos. E eu... eu achava que meus colegas entendiam tanto... eu nunca havia entrado de verdade no universo da Biologia... Aí vem essa frasezinha aqui... Então eu falei: - É com esse que eu vou!

Rita traduziu o livro Sharing Nature With Children, do professor Cornell e, em 1996, promoveu a vinda dele para o lançamento no Brasil. Desde então, ministrou cursos com a metodologia do professor Cornell pelo Brasil e ampliou seu contato com as técnicas da Sharing Nature Foundation - entidade internacional voltada para o desenvolvimento de atividades de percepção da natureza - tornando-se sua coordenadora no Brasil. Foi esse seu envolvimento com a questão ambiental que culminou na criação do Instituto Romã de Vivências na Natureza.

Mônica Pilz Borba é pedagoga com experiência em educação infantil e diretora e sócio-fundadora do Instituto 5 Elementos. Especializou-se em Educação Ambiental (EA) 
pela USP e em Teoria e Prática do Meio Ambiente pela CETESB (SP). Coordenou vários programas e publicações de EA que receberam o Prêmio Itaú Unicef em 1997.

Em entrevista concedida no dia 28/06/2003, em São Paulo, contou que fez um curso de Arte-educação quando ainda tinha 17 anos, tendo, durante um ano, aulas com grandes nomes da área de Educação. Foi assim que se aproximou da Antroposofia e descobriu o universo das questões orientais, da Yoga, da alimentação natural.

Fez parte de grupos Bandeirantes, entre os 17 e os 20 anos, quando então participou de grandes viagens pelo Brasil e teve contato intenso com natureza. Fazia trabalhos temporários no natal e, com o dinheiro conquistado, viajava com seus amigos. Chegou a "descer" o rio São Francisco e a pegar carona até Fortaleza (CE). Essas e outras oportunidades lhe proporcionaram um grande conhecimento sobre o país e a sua realidade, não só relacionado à natureza, mas também à população marginalizada e à pobreza. Para Mônica, vivenciar tais experiências foi fundamental para sua adesão à questão ambiental, como declarou:

\begin{abstract}
- Quando eu era criança, queimei a minha mão e passei umas férias inteiras com a mão queimada... Eu tinha onze anos, ou seja, já não era tão pequena. Eu sabia muito bem, mas eu acabei queimando a mão num lampião a gás... Mas nunca deixei de gostar de fogo por causa disso, e sim a respeitá-lo. Então essa coisa do respeito, do medo, do prazer, acho que é só vivenciando mesmo que se adquire... Comigo foi assim. Eu vejo assim: é preciso que as pessoas vivenciem mais. Não acho que vamos criar pessoas que gostem da natureza sem conviver com ela...
\end{abstract}

Mônica decidiu cursar Pedagogia na PUC (SP) porque queria contribuir um pouco para a mudança de concepção da escola chata para uma escola prazerosa. Logo teve a oportunidade de trabalhar durante dez anos numa escola particular com uma visão de educação que lhe ensinou muito sobre como não "apertar" os alunos, como fazer o conhecimento realmente ser algo dentro do timing de cada aluno, envolvendo muito prazer em cada atividade.

Desde que terminou a faculdade, Mônica começa a frequentar a ONG Pró-Jureia. Lá, participou da criação de um centro de EA. Com os contatos que fez, monta, juntamente com outros colegas, um grupo de estudos sobre EA e analisa como esse tema pode ser inserido na escola.
Esse grupo de estudos foi o berço do Instituto 5 Elementos, fundado em 1993.

Os projetos dentro da instituição cresceram no mesmo ritmo que a EA neste mesmo período. Mônica e sua equipe passaram a atuar em parques urbanos oferecendo às crianças um aprendizado prazeroso, junto à natureza, sobre as questões socioambientais urbanas. Outros projetos, como a implantação de sistemas de coleta seletiva de lixo a partir da capacitação de professores e palestras para alunos, fizeram-na aprender muito sobre o funcionamento de instituições do terceiro setor e a viabilização de projetos. Porém, como ela achava que os resultados eram um tanto tímidos frente às questões ambientais que enfrentamos na atualidade, começa a colaborar, a partir de 1998, com a reconstrução e fortalecimento da Rede Paulista de Educação Ambiental (REPEA), onde atua, desde 2003, como coordenadora da Secretaria Executiva.

Maria Cecília Wey de Brito, a Ciça, foi Diretora do Instituto Florestal de São Paulo e já exerceu a função de Coordenadora do Núcleo Picinguaba do Parque Estadual da Serra do Mar, do Programa Estadual para Conservação da Biodiversidade (PROBIO), e da Aliança para a Conservação da Biodiversidade (IUCN).

Em entrevista concedida no dia 24/06/2003, em São Paulo, relembrou que desde criança frequentava, com seus pais, as pequenas fazendas de criação de gado em Mato Grosso do Sul, nas quais os próprios donos são também os empregados.

Ciça lembra que durante o curso fundamental ficava muito impressionada com os comentários dos professores sobre o sol deixar de existir daqui a cinco bilhões de anos. Isso provocava nela um sentimento de que alguma coisa precisava ser feita.

Seu pai deu aos filhos uma formação conservadora. Assim, as coisas tradicionais, o "como era bom antes", foram muito marcantes nas experiências da infância de Ciça vividas nas fazendas. Havia um contraste cultural muito grande entre o que era a sua vida urbana e a vida cotidiana daqueles fazendeiros, fato que lhe proporcionou muito aprendizado. Como o seu pai contava muitas histórias da sua vida, Ciça sentiu-se apegada a um tempo histórico que, mesmo não vivido, se tornou o seu próprio.

Em 1979, ingressa no curso de Agronomia da Escola Superior de Agricultura “Luiz de Queiroz” (ESALQ). Nessa época, Ciça sabia que gostava muito de Biologia, mas acre- 
ditava que a profissão de "professor", a única possibilidade que lhe parecia destinada a esses profissionais, era muito pouco para ela. A Agronomia parecia juntar sua vivência na fazenda com o seu interesse pela Biologia.

Quando concluiu o curso, em 1982, Ciça foi visitar, no Instituto de Pesquisas Tecnológicas (IPT), uma equipe que trabalhava com Geologia Aplicada e desenvolvia um projeto de irrigação e módulos agrícolas no Nordeste. Mesmo sem remuneração, ela começou a trabalhar como estagiária nessa área, fazendo cálculos sobre a boa composição de ração para aqueles animais do semiárido.

Por indicação de técnicos do IPT, Ciça vai trabalhar, ainda sem remuneração, na Superintendência para Desenvolvimento do Litoral Paulista (SUDELPA), órgão que na ocasião cuidava de uma área no Estado de São Paulo e dava apoio aos agricultores locais, principalmente bananicultores, numa região muito conservada.

Na ocasião, já tinha sido viabilizado pelo Governo um projeto que se chamava "Grupo de Resolução de Conflito de Terra”. Ciça foi então contratada e teve que trabalhar com agricultores em conflitos de terra, dispensando as técnicas agrícolas que havia aprendido na faculdade (tecnicidade, mecanização etc.). Essa experiência faz com que, em 1986, Ciça escreva um documento para os seus coordenadores, solicitando autorização para trabalhar apenas com a temática ambiental.

As áreas de conflito com as quais ela trabalhava eram quase todas dentro de Unidades de Conservação, já estabelecidas com tal denominação naquela época. Assim, esses temas começaram a ser, na verdade, necessários para o seu trabalho. No contexto em que estava vivendo é que começou, de fato, a trabalhar com a questão do meio ambiente, pesquisando de forma autodidata. Apesar do contato com a natureza, que acompanhou sua infância na fazenda, esse trabalho parece ter sido o fato mais significativo na sua adesão a questão ambiental, como declara:

- Esse trabalho nosso de conflito de terra nos fez andar muito a pé, literalmente, no Vale do Ribeira e litoral. Muito! E, ao fazer isso, obviamente você toma contato com essas áreas naturais, com rio, com cachoeiras e com matas que têm sua conservação já bastante resolvida. E isso cria em você um certo prazer, uma certa necessidade até de ter que ir a esses lugares, de ter que vivenciar aquilo com mais frequência. E aí, para você poder fazer isso, e talvez isso seja um ponto interessante, vem aquela história de você vivenciar para poder saber como é legal, como eu devo querer ter isso sempre, e ter isso sempre significa conservá-lo de alguma forma. Então, por ter que fazer essas andanças, eu passei a ter muito mais acesso a isso, gostar de fazer isso, era diferente de quando eu ia às fazendas, mesmo aquelas de áreas ainda bem conservadas do Mato Grosso do Sul. $\mathrm{O}$ ecossistema era totalmente diferente. No cerrado, eu tinha contato com seriema, cobra, arara, sei lá, e outros bichos mais específicos do Cerrado, e de repente eu vou para um outro sistema que era até mais (ou deveria ter sido) particular meu, a Mata Atlântica, mas com o qual eu tinha pouco contato. Foi então que se juntaram essas duas leituras e aí eu acho que a coisa deflagrou.

Em 1987, a sociedade paulista começou a discutir muito mais a fundo a questão da Estação Ecológica da Jureia-Itatins, o projeto de usina nuclear da Nuclebrás e todas as brigas que decorreram daquele conflito. Nessa época, Ciça acompanha a passagem do Núcleo Picinguaba em Ubatuba (SP) para o Poder Público, assiste à aparição da "Associação em Defesa da Jureia" e a criação da "SOS Mata Atlântica", enfim, a gestação de toda uma fase do movimento ambientalista paulista. Apesar de não exercer a liderança, ela estava muito próxima desses fatos.

Nessa época, conseguiu uma bolsa de estudos no Canadá para trabalhar na área de Parques, oportunidade que foi mantendo-a sempre ligada à área de conservação. Em 1987, quando é criada a Secretaria Estadual de Meio Ambiente, Ciça foi contratada para trabalhar lá. Daí para frente continuou trabalhando, até hoje, com nuances no foco, basicamente na área de conservação ambiental. Essa trajetória culminou com o cargo de Diretoria do Instituto Florestal de São Paulo, que exerceu entre 2003 e 2007.

Marcelo Teixeira César de Oliveira é Diretor-Presidente da ONG "Ipá Ti-Uá - Vivência Ambiental" e dedica-se à execução de projetos de EA, além de ser professor e jornalista free-lancer. Já recebeu dois prêmios de jornalismo por matérias escritas sobre Meio Ambiente e foi coautor do livro Aves no Pantanal.

Em entrevista concedida no dia 20/06/2003, em São Paulo, relembrou que seu estímulo para as questões da natureza veio da família. Seus avós sempre tiveram ligação com plantas, com animais, com a natureza. Seu pai velejava nas represas Guarapiranga e Billings, bebeu água e remou no rio Tietê, foi um dos primeiros a fazer mergulho autônomo no 
Brasil e a visitar a Caverna do Diabo já em 1958. Marcelo, quando criança, cuidou de cachorros, deu remédios para periquito, teve contato com tartaruga, araras, papagaio, codorna, preá, aquário, lagarto, e esse estímulo ele recebia da sua avó e de seu pai.

Durante muitos anos sua família teve o hábito de viajar de forma intercalada entre litoral e interior. Em Piracicaba-SP, Marcelo andou no meio do mato, pescou no rio e visitou o sítio de um tio especialista em Nematóides na ESALQ, que foi uma das pessoas que mais lhe influenciaram. Esse tio plantou espécies do mundo inteiro, espécies que ele trazia das viagens que fazia como professor de agronomia. Eram mais de 200 árvores frutíferas que Marcelo não conhecia, mas das quais adorava provar os frutos, um a um.

O pai de Marcelo sempre o estimulou em suas muitas habilidades para que o garoto pudesse usar um pouco de tudo. O estímulo para a natação, por exemplo, lhe deu segurança para o mergulho. Essa influência parece ter sido decisiva na sua adesão à causa ambiental e, sobre seu pai, Marcelo declara:

- Meu pai era um cara inquieto. Quando chegavam para ele e falavam "olha, a cachoeira está bonita ali”, ele não queria só a imagem: ele queria ver se a água do rio estava legal ou não. Então ele pegava a trilha e entrava no mato, sem medo. Ele sempre teve um espírito um pouco aventureiro. Por exemplo, ele sempre quis dar a volta ao mundo de veleiro, mesmo nunca tendo dinheiro para isso, esse era um sonho que ele alimentou a vida inteira. Ele leu tudo que podia sobre essas coisas, e ficava ligado nesse tipo de literatura. Nós tivemos em casa a National Geographic desde que eu era nenezinho. Eu não sabia ler nada em inglês, mas todas aquelas imagens das culturas, dos lugares, dos povos, ficaram gravadas na cabeça.

Quando estava no terceiro ano da escola técnica de eletrônica, teve que decidir qual área iria escolher para o vestibular. Após analisar o material do cursinho, teve uma convicção, que ele não sabe bem de onde veio, e decidiu que iria fazer Biologia.

Em 1981, ingressou no Instituto de Biociências da USP. Enquanto frequentou a faculdade, Marcelo se destacou pelo envolvimento em projetos paralelos, como a publicação de jornal dos alunos e a realização de atividades de campo, o que lhe valeu, em 1984, um convite para trabalhar na
ONG "Eco-Associação". Lá tomou gosto pelo trabalho de EA por meio de visitas ao ambiente natural.

Desencantado com o curso, abandonou a faculdade de Biologia e fundou, em 1988, a ONG Ipá Ti-Uá - Vivência Ambiental, juntamente com outros ex-colegas de curso, tornando-se seu Presidente. Desde então, vem se dedicando à projetos de EA e publicando artigos em diversos periódicos nacionais. Torna-se professor de cursos na área de Meio Ambiente e publica livros sobre o tema. Em 2006, retoma os estudos de graduação e se forma em Ciências Biológicas. Em 2007, ingressa no curso de Mestrado do Departamento de Geografia da Universidade de São Paulo.

Mário Barroso Ramos Neto é Doutor em Ecologia e gerente do programa de conservação do cerrado da Conservation International, tendo atuado no setor público e em ONGs com projetos na área ambiental.

Em entrevista concedida no dia 14/07/2003, em Mineiros - GO, contou que, quando criança, morou na periferia de São Paulo, tendo uma infância bem tranquila. Naquele tempo, havia no seu bairro muito terreno desocupado, com mato, insetos, sapos e um rio com nascente limpa, onde ele sempre brincava com a terra e fazia pequenos passeios.

$\mathrm{Na}$ casa de seu avô, Mário gostava de brincar arrancando folhas e flores de árvores e mexer com insetos. Para ele, nunca houve a proibição de tocar ou admirar as coisas da natureza, ao contrário, essa interação sempre foi muito intensa e vai marcar todo o futuro do jovem biólogo.

Durante boa parte de sua infância e adolescência passou férias em Iguape-SP, pois seu avô, que era engenheiro agrônomo, tinha projetos na região. Apesar de conviver pouco com ele, a figura do seu avô marcou muito seu imaginário, pois foi um agrônomo pioneiro, que ia para as regiões mais distantes do Brasil para ensinar novas tecnologias, buscar alternativas e organizar cooperativas. A influência do avô fica evidente neste depoimento:

- Ele foi para Iguape coordenar um projeto com seringueira. Era uma pessoa "do mato". Eu nunca o acompanhei, pois ele morreu quando eu tinha uns dez anos, mas para mim ele era um cara que tinha uma biblioteca, que tinha todo um mistério... usava bota... tinha um chapéu de campo... Era toda uma coisa que me marcou muito. E lá em Iguape eu tive um contato muito grande com a natureza. Eu gostava de andar no mato, sempre gostei de fazer essas coisas, de me embrenhar em áreas desconhecidas, assim como fazia meu avô... 
Outro marco importante em sua vida foi o exemplo do naturalista Jacques Cousteau, cujos documentários eram exibidos na televisão.

- A visão do aventureiro, não do cientista, mas da aventura, de quão legal é estar em um ambiente selvagem, de estar fazendo uma coisa diferente. Isso, realmente, em um moleque de uns seis, sete anos, deve ter tido uma influência grande.

Por influência de um professor do ensino médio, Mário decidiu que iria cursar Biologia. Ingressou na faculdade logo na primeira tentativa, e isso representou uma grande mudança na sua vida. Por frequentar o curso noturno do Instituto de Biociências da USP, pôde, durante o dia, vivenciar todos os aspectos da vida social na universidade, o que foi para ele um deslumbramento. Ao final do primeiro ano de faculdade já estava estagiando, repetindo a experiência durante todo o período de estudos, o que lhe proporcionou contato com as diferentes áreas da Biologia. Pesquisou fitossociologia de restinga e, em seguida, conseguiu uma bolsa de estudos no Instituto Butantã para trabalhar com manejo de cobras em cativeiro, onde permaneceu um ano. Trabalhou, também, por um pequeno período, como monitor de atividades de EA, pela empresa "Biotrip".

Em seguida, fez seu mestrado, estudando a caracterização da restinga da Estação Ecológica dos Chauás, após o que, foi convidado a trabalhar por seis meses, como consultor de uma empresa, no projeto "Olho verde", da Secretaria Estadual do Meio Ambiente, cujo objetivo era fazer um mapeamento da cobertura vegetal do Estado.

No Instituto Florestal, foi contratado para trabalhar com o Parque Estadual de Jacupiranga, coordenando uma equipe que cuidava da regularização fundiária. Após ser demitido, passa por um período de transição, seguido de um doutorado com o Parque Nacional das Emas-GO.

Sua história com o Parque das Emas é bem emblemática. Em 1986, numa viagem com amigos, pôde conhecer o Sr. Antônio Malheiros da Cruz, na época o Diretor, que era um defensor apaixonado da região e adorava receber visitantes de uma maneira muito especial. Seu exemplo de vida influenciou muitas pessoas a se engajarem na causa ambiental, e não foi diferente com Mário. Nessa mesma viagem ele avistou pela primeira vez um tamanduá-bandeira, e esse encontro mudou sua vida. Seu depoimento reflete bem o sentimento que teve na época:
- E... puxa vida, foi uma coisa fantástica na minha vida... Principalmente por causa do senhor Antônio Malheiros... Seu Antônio Malheiros era... nós fomos recebidos como... nossa... como pessoas muito especiais! Ele nunca tinha visto a gente, mas todo mundo foi tratado como pessoas especiais, mesmo depois, nas outras vezes todas em que a gente voltou. $\mathrm{O}$ fato de hoje eu estar aqui é culpa do seu Antônio Malheiros. 1986... foi uma experiência que marcou minha vida. Sempre que dava, eu voltava. E era até competição, a gente competia: quantas vezes cada um tinha ido ao Parque das Emas, que bichos tinha visto, quantos dias a gente tinha ficado... ...Acho que no mestrado eu resolvi uma coisa com o meu avô, eu fui trabalhar em Iguape, que era o lugar que meu avô gostava, e no doutorado eu fui trabalhar no Parque das Emas, que era uma outra coisa que estava mal resolvida na minha vida.

Como pesquisador do manejo de fogo na área protegida do Parque das Emas, teve a oportunidade de passar alguns meses morando no Parque. No mês seguinte ao término de seu doutorado, em 2000, foi convidado a trabalhar junto à "Fundação Emas", para coordenar o projeto "Corredor Cerrado-Pantanal". Em 2002 é transferido para a gerência do programa de conservação do cerrado da Conservation International, onde trabalha até hoje.

\section{Análise dos momentos de adesão e opinião sobre a Educação Ambiental}

No ato de falar e ouvir, de narrar experiências de vida, de lidar com o tempo como algo mais dinâmico e lúdico, no qual o ontem se perdeu e o hoje se perde na expectativa do amanhã, os homens têm a possibilidade de se humanizarem, deixando de ser objetos de uma dada história para se converterem em sujeitos que contam e fazem suas próprias histórias (ABREU, 2000).

A reconstituição da história de vida é vista como transformadora e reconstituinte do sujeito, na medida em que ele toma consciência das nuanças de seu percurso, podendo ressignificar suas experiências, sair de uma posição de alienação frente à História, situando-se, por meio de sua história, como agente de sua vida e da coletividade. Portanto, independentemente de como o sujeito se situa perante 
sua história, ele teria as possibilidades de inserir-se no social de modo diverso, já que recuperaria, ou melhor, talvez nele se instaurasse a dignidade de ocupar um lugar de sujeito, de agente perante o mundo e sua própria vida (TEIXEIRA, 2003). Como agente da construção social da questão ambiental, sente-se coautor do sentido que as pessoas dão ao mundo e colaborador na transformação dos problemas em algo público, conforme descrito por Hannigan (1995).

Quando um acontecimento público interfere na opinião de determinado grupo social,

[...] a memória de cada um de seus membros é afetada pela interpretação que a ideologia dominante dá desse acontecimento. Portanto, uma das faces da memória pública tende a permear as consciências individuais. É preciso sempre examinar matizando os laços que unem memória e ideologia (BOSI, 2003, p. 21-22).

Ao narrar sua história e, através dela, sentir-se inserido na elucidação da causa e efeito dos problemas, cada entrevistado manifestou certa satisfação em fazer parte do "coro dos justos", daqueles que são os guardiões de uma causa nobre e moralmente desejada: a defesa do meio ambiente. É evidente o quanto seus discursos vêm carregados da ideologia do grupo ao qual pertencem. No entanto, como o que interessa neste estudo é a compreensão dos momentos decisivos para a adesão à causa ambiental, seu significado para a vida de cada entrevistado e seu agente eliciador, algumas considerações se fazem necessárias:

Se opinião e conhecimento requerem um conteúdo de consciência individual, uma apropriação subjetiva, esse momento egótico é perigoso, escorrega para o falso. As motivações que estão por trás da opinião (aplauso do grupo, segurança, repouso no estereótipo) são diferentes das que estão por trás da verdade. Não se trata de procurar uma simples congruência interna de fatos. Deve-se confrontar cada asserção com a experiência e voltar para as coisas (BOSI, 2003, p. 123)

Além disso, a crença da eficácia da narrativa da história de vida como método de pesquisa pressupõe ser possível um conhecimento racional, uma consciência de si mesmo, como se essa tivesse a possibilidade de abranger toda a história do sujeito através do recurso da memória. No entanto, como fonte de dados, as autobiografias só adquirem importância quando evocadas por um objetivo de pesquisa alheio ao próprio autor, que só se constitui como tal quando o mesmo é convocado a participar de uma amostragem (TEIXEIRA, 2003). Só ganham significado especial na narrativa autobiográfica fatos que, na existência anterior do indivíduo, provocaram uma mudança ou transformação radical e, portanto, impregnaram perenemente a memória. Se a mudança não afetou diretamente a vida do narrador, a matéria apta a tornar-se objeto de uma narração limitar-se-ia à série de eventos exteriores, mais condizentes à efetivação da "história", que prescinde de um narrador em primeira pessoa. Ao contrário, a transformação interna do indivíduo provocada por eventos externos proporciona material para uma narrativa que tem o eu como sujeito e como objeto, sendo que a importância da experiência pessoal, aliada à oportunidade de oferecer o relato dela a outrem, estabelece a legitimidade do eu e autoriza-o a tomar como tema sua existência pretérita (MIRANDA, 1992 apud TEIXEIRA, 2003).

Atentos a essas ressalvas e analisando os depoimentos desses atores do cenário ambiental, é possível detectar-se nas narrativas muitas similaridades quanto aos seus "momentos de adesão", revelando alguns fatos marcantes que possibilitam a defesa da ideia de que o contato com o ambiente natural, aliado à influência cultural (manifesta na influência que algumas pessoas ou situações de convívio social exercem sobre a formação de opinião), são os pressupostos básicos da gênese de atitudes pró-ambiente.

Para facilitar a evocação das histórias de vida, as perguntas exploratórias foram feitas com o cuidado de dar aos entrevistados a liberdade de encadear e compor como quisessem os momentos do seu passado. As entrevistas foram conduzidas de modo a expor fatos e idéias que se ativessem ao objeto de estudo.

O exemplo de outras pessoas, ou organizações, referências e lugares parece realmente ser fundamental. Para Mário, o avô e o Sr. Antônio Malheiros foram as peças cruciais na sua trajetória. No caso da Ciça, em termos profissionais, não houve nenhuma pessoa, ou nenhum fato específico, mas um conjunto deles que a levaram para a "direção" ambiental. No entanto, ela se lembra de um professor de biologia, que "era excelente e tinha uma didática maravilhosa" e que teve papel determinante no seu prazer por estudar essa matéria. Para Rita, foi com a aproximação do Prof. Cornell que começou a ter um contato mais amplo 
com a natureza e a treinar as atividades por ele sugeridas. No caso do Marcelo, o papel exercido pelo pai e avó também é bem explícito no seu depoimento.

Mas é, sem dúvida, nas experiências de contato com a natureza ou em situações vivenciadas que encontramos os mais claros motivos para a adesão à causa ambiental. "Se a memória é não passividade, mas forma organizadora, é importante respeitar os caminhos que os recordadores vão abrindo na sua evocação porque são o mapa afetivo de sua experiência e da experiência do seu grupo" (BOSI, 2003, p. 56).

Mário conheceu diversas Unidades de Conservação (como o Parque Nacional das Emas, que para ele é um lugar especial) com as quais teve, e ainda tem, uma ligação muito forte. Na sua opinião, nem toda área é suficientemente estimulante para o emocional, para gerar um vínculo, sendo poucos os lugares que realmente inspiram e tocam.

Quando Ciça optou pelo curso de Agronomia, estava tentando unir o "útil" (estudar biologia) ao "agradável" (aquilo de que ela mais gostava nas férias: estar na fazenda). Foi uma tentativa de junção entre o prazer de vivenciar aquela história de fazenda com a técnica, o saber como funciona. Seu apego pelo natural manifestou-se desde muito cedo, ainda na adolescência, nas oportunidades de visitar, com os amigos, montanhas e praias, como pode ser visto neste depoimento:

- A gente andava muito a pé em Campos do Jordão (SP), ficava fuçando para lá e para cá, andando atrás de alguma coisa que a gente não sabia bem o que era, tipo, "vamos atrás do Lago Azul", que nunca ninguém soube se existia. Em Ubatuba (SP), era essa coisa de andar de barco, mergulhar, às vezes, e ir até as praias mais desertas... Quer dizer, isso foi um pouco o tom da nossa adolescência.

Para Ciça, a experiência do contato com a "diferença" é muito transformadora, e se o indivíduo está aberto para ela, pode aprender muito. No seu caso, foi um pouco a insatisfação com o trabalho exclusivamente técnico, que desempenhava junto às comunidades tradicionais que visitava, que lhe conduziu a encontrar uma solução pessoal e incorporará-la às questões ambientais. As primeiras vezes em que viajou como membro de um grupo técnico para o Vale do Ribeira não foram fáceis: teve que andar de botas, tomar banho frio, dormir em casas de taipa, mas tudo isso teve um grande sentido de contato com a diferença, um certo espírito de "aventura", de chegar e poder falar fui para um lugar que ninguém conhecia. Seus pais se orgulhavam muito de seu trabalho com indios e esse era o assunto mais interessante para eles conversarem com os amigos... E Ciça gostava dessa aceitação.

Já no caso da Rita, ela adotou radicalmente o princípio de que é preciso conhecer para gostar; gostar para preservar, e que os sentimentos têm sempre que ser evocados nos trabalhos de EA. Quando questionada sobre o porquê da sua demora em se aproximar da natureza, Rita respondeu:

\begin{abstract}
- Você conhece aquela história do Nasrudim? Ele tinha perdido as chaves e não as encontrava. Era noite e ele começou a procurar as chaves debaixo de um poste, aí passou um amigo e perguntou: "O que é que você está procurando?" E ele falou: “As chaves que eu perdi”. Aí, o amigo perguntou: "Mas onde foi que você perdeu a chave?" E Nasrudim respondeu: "Acho que foi lá dentro de casa". "Mas por que é que você está procurando aqui?", "Por que aqui tem luz"... Então, eu acho que aconteceu comigo um pouco isso. Eu estava procurando uma coisa no lugar errado. E, quando eu achei o lugar, ele já era... A Natureza é a fonte e comigo levou trinta e cinco anos para acontecer. Quer dizer, não é uma questão de tempo, poderia ter demorado um segundo... É uma coisa que já estava em mim, mas eu não me deixava perceber... Eu não teria argumentos para explicar isso para você...
\end{abstract}

Marcelo teve oportunidades de contato com a natureza desde a tenra idade, o que o ajudou muito a não ter medo, saber lidar, saber pegar, saber cuidar, e saber alimentar. Os lugares que ele vivenciou, como Boissucanga, eram muito isolados e, por diversas vezes, ele esteve só na praia. Passava até três meses mergulhando, andando, fazendo trilha, sozinho, como relata:

- Então tive contato com a cultura caiçara de verdade, e isso ajudou. Tudo isso a gente acabou aprendendo: Tomar picada de abelha, de vespa, andar descalço... Eu sempre tomei espetada de ouriço no costão rochoso, mergulhando (mete a mão, fura a mão)...

Em todos os relatos revela-se fortemente o contato com a natureza, quer seja porque de fato se constituem em "marcos de adesão a causa ambiental", quer pela reconstru- 
ção que fazem das próprias experiências através da ideologia construída ao longo de sua trajetória. Para Bosi (1994),

[...] na maior parte das vezes, lembrar não é reviver, mas refazer, reconstruir, repensar, com imagens e idéias de hoje, as experiências do passado. A memória não é sonho, é trabalho. Se assim é, deve-se duvidar da sobrevivência do passado, "tal como foi", e que se daria no inconsciente de cada sujeito. A lembrança é uma imagem construída pelos materiais que estão, agora, à nossa disposição, no conjunto de representações que povoam nossa consciência atual. Por mais nítida que nos pareça a lembrança de um fato antigo, ela não é a mesma imagem que experimentamos na infância, porque nós não somos os mesmos de então e porque nossa percepção alterou-se e, com ela, nossas ideias, nossos juízos de realidade e de valor. O simples fato de lembrar o passado, no presente, exclui a identidade entre as imagens de um e de outro, e propõe a sua diferença em termos de ponto de vista (p. 55). (...) A memória poderá ser conservação ou elaboração do passado, mesmo porque o seu lugar na vida do homem acha-se a meio caminho entre o instinto, que se repete sempre, e a inteligência, que é capaz de inovar (p. 68).

Se o contato com a natureza é recorrentemente narrado como fonte de prazer e satisfação, isso é um forte indicativo do seu papel como eliciador de atitudes pró-ambiente. A construção ideológica, fruto do momento social, revela-se marcante na formação da opinião, mas não se mostra mais presente do que as evocações afetivas dos depoentes. E todas as suas vivências pessoais (afetivas e cognitivas) fazem com que os mesmos tenham muita clareza sobre as melhores estratégias para o desenvolvimento de metodologias para a EA.

Para Mario, apenas a informação não é suficiente; é preciso preparar o espírito, os olhos e os sentidos das pessoas. Sem essa preparação, elas passam, olham, mas não entendem nada. É preciso acionar o lado emocional, não no sentido de "emoção barata", mas do envolvimento, criando um vínculo da pessoa com aquilo que ela está conhecendo. Com crianças, isso é muito claro. Se o educador consegue despertar a atenção da criança, seu interesse, ela quer saber mais, e pergunta, e tenta interagir com o que se está mostrando. Se, ao contrário, o educador simplesmente fala (dá uma palestra), a criança escuta, acha interessante, mas, depois, não fica nada. Com certeza a experiência de contato é muito importante, e quem faz isso com competência é mais importante ainda.

Marcelo compartilha da mesma opinião: é preciso haver um estímulo, alimentar a curiosidade natural da criança. Há casos de escola que, em viagens à natureza, proíbe os alunos de tomarem banho no rio, ou cachoeira, em nome da segurança, o que reforça o distanciamento. Tal postura realimenta o sentimento de culpa pela "destruição da natureza" que tem acompanhado essa geração. Se não deixarmos as pessoas enfrentarem as possibilidades de desafios, então é melhor não começar a fazer nada e fechar a porta dos parques. É preciso trabalhar com conteúdos, com desafios, com o lúdico, mexer com as questões psicológicas, sempre observando os aspectos de segurança, para que a pessoa não sofra pequenos acidentes.

Na opinião de Mônica, o contato com natureza é muito importante, pois ela percebeu, em palestras para professores, que os mais velhos, que tiveram esse contato de maneira mais intensa que as crianças de hoje, lembram de coisas muito prazerosas. E isso é uma questão de valores, que deveria ser muito mais trabalhada nas famílias. Infelizmente, as poucas áreas verdes que existem nas escolas estão sendo asfaltadas ou cimentadas. Assim, os parques públicos, hoje subtilizados, deveriam ser "escolas a céu aberto". Para ela, é importante andar descalço, fazer meleca, e na pré-escola pode-se fazer isso sempre, com muita eficácia. É preciso levar as crianças a viajarem mais, pois fica muito difícil fazer com que respeitem o ambiente natural se elas não gostam dele, se elas não têm prazer com ele.

Marcelo tem uma opinião semelhante. Para ele, as crianças, quando visitam os parques, desejam tocar, mexer, experimentar. Assim, é preciso deixar algum lugar para elas manipularem, cheirarem, sentirem, caso contrário nenhum vínculo será estabelecido. O contato com um lugar natural possibilita a quebra de couraças e carapaças, tornando as pessoas distantes das cobranças sociais, mais motivadas a enfrentar "aventuras", mais abertas a ouvir ideias novas.

E Rita vai ainda mais fundo na análise das possibilidades do contato com a natureza, que, para ela, se for bem trabalhado, torna-se revelador. Vejam sua opinião:

- Você é terra, você é mosquitinho, você tem uma identidade, você sente uma identidade com o mundo... Algo que nos é próprio, que é a coisa da identidade terrena, que nos fala o Edgar Morin. Você percebe que é como se de repente você se imaginasse dentro de 
uma espaçonave. Só dá para viver se ambos existirem, tanto um quanto o outro, naquelas condições. E isso dá para você explicar na sala de aula, mas é a abordagem explicativa. Em campo, não precisa explicar, a pessoa percebe, ela se dá conta. Não é porque você explicou que ela vai se dar conta.

Para Rita, a função do Educador é fazer com que através do contato, as pessoas se deem conta de sua ligação com natureza. A situação do mundo hoje necessita de transformações grandes, que devem ser criadas no nosso sistema de pensamento. Existe uma cisão na mente do ser humano moderno, uma separação, que não o permite unir o desejo com a ação. Isso é perceptível diariamente: apesar de não querer contribuir com a poluição da nossa cidade, andamos de carro, vivemos essa contradição.

Numa perspectiva mais generalista sobre a questão da relação do ser humano com a natureza, Ciça acredita que há uma resistência totalmente cultural, urbanoide, ao contato. A pessoa que domina, que sabe se virar super bem na cidade, de repente, numa outra condição, na qual fica mais exposta que outras, como, por exemplo, atravessar uma pinguela e, ao contrário de todos os demais que o fazem muito bem, cair ou ser obrigado a atravessar sentado, vê sua autoconfiança cair a zero.

Para Marcelo, não se trata apenas de um medo em si do contato com a natureza. O problema de muitos "urbanoides", hoje, é que eles não têm esse contato inicial, e aí acabam criando um "monstro", ficando com temor, porque não fizeram aquilo na época da infância.

Ciça acredita que a motivação, para as viagens, dos que estão mais conscientizados, não se resume exatamente em ir a um lugar, ou atravessar uma cachoeira. Os propósitos ideológicos para a vida, que não sejam "ganhar dinheiro", pesam nessa opção. Se há paixão por uma causa, essa paixão faz com que as pessoas sejam capazes de dedicar sua vida por ela.

Marcelo aponta que, se o ser humano não tiver contato com muitas das milhões de espécies existentes, manterá sempre uma postura extremamente arrogante, uma atitude até desprezível. Nossa capacidade de usar a tecnologia para transformar o ambiente não nos dá o direito de pisar no que está em volta. Para ele, um exercício que as pessoas têm que fazer é olhar para o lado, sair desse foco centrado só no humano, mudar a concepção de um mundo baseado só em economia, dinheiro, crescimento, poder.
Rita atribui tal concepção ao pensamento linear, que redunda em certos círculos viciosos, uma vez que a realidade não é linear. Fica difícil resolver problemas práticos, e infelizmente a ciência não trará a resolução dos problemas. Nem a ciência, nem a tecnologia, porque isso é um assunto de outra natureza. Tratamos a questão ambiental de uma maneira linear, mas fazemos parte de um sistema. Assim, a questão se resolve num determinado momento, mas, passando o tempo natural de espera do sistema, o problema volta a reaparecer. Estamos o tempo todo repetindo um erro por não buscar outra maneira de estruturar o pensamento. Para isso, é preciso uma ativação de uma energia mental totalmente nova. Nosso sistema escolar, por exemplo, é todo esquematizado, é todo padronizado. Por mais que se queira uma coisa nova, ao usar a estrutura antiga, inibem-se as brechas por onde essa energia nova pode aparecer. Rita é defensora das metodologias do prof. Cornell por acreditar que elas fazem isso, com muita maestria. É no contato com uma essência que se dá a mudança do pensamento linear para o sistêmico. Isso é fundamental para todos e Rita acredita que isso se dá na natureza:

- Sabe, assim, quando você fica olhando para uma plantinha, escuta o som do passarinho, faz alguma coisa que não seja usual para você... É daí que vão surgir as respostas! Para mim faz sentido, porque isso aconteceu comigo. O processo civilizatório foi tirando as nossas raízes. Eu sinto que o que nós estamos precisando, e que a natureza pode nos ensinar, é o caminho para nos re-humanizarmos. A nossa humanidade está na natureza!

Para Rita, a nossa consciência passa pelas anteriores (desde os estágios dos homens primitivos) e se constitui em nossas raízes. Quer dizer, para sermos de fato seres evoluídos, tendo como base o nosso próprio processo histórico, a nossa própria experiência humana, não podemos negar essas bases. E essas bases vêm do homem imerso na natureza antes de criar as sociedades. Esse é o nosso passado, e é o nosso futuro também.

\section{Considerações finais}

Vale, por fim, ressaltar, mais uma vez, que os depoimentos apresentados neste estudo não podem ser generalizados. Não representam senão a opinião de alguns atores 
sociais que, manifestamente, declaram-se atuantes na questão ambiental e, portanto, com evidentes manifestações das atitudes pró-ambientes. Foram colhidos e analisados com o intuito de ilustrar qualitativamente algumas questões que

\section{Referências}

ABREU, R. Subjetividade, alteridade e memória social em Ruth Landes. In: ENCONTRO ANUAL DA ASSOCIAÇÃO NACIONAL DE PÓS-GRADUAÇÃO E PESQUISA EM CIÊNCIAS SOCIAIS - ANPOCS, GP 1, XXIV. Anais. Memória social e biografias. Petrópolis, 2000.

BOSI, E. Memória e sociedade - lembranças de velhos. 3 ed. São Paulo: Cia das Letras, 1994. 2003. . O tempo vivo da memória. São Paulo: Ateliê Editorial,

CARVALHO, I. C. M. A invenção ecológica: narrativas e trajetórias da educação ambiental no Brasil. Porto Alegre: Editora da UFRGS, 2001.

HANNIGAN, J. Environmental Sociology. London: Routledge, 1995.

KRAMER, S.; SOUZA, S. J. (Orgs.). História de professores: Leitura, escrita e pesquisa em educação. São Paulo: Ática, 1996. se mostraram relevantes nos estudos sobre EA. Reforçam a necessidade dos trabalhos de educação se voltarem para o contato com a natureza, contato este que deve ser intenso e dirigido.
MINAYO, M. C. S. O desafio do conhecimento: pesquisa qualitativa em saúde. 4. ed. São Paulo: Hucitec, 1996.

MIRANDA, W. M. Corpos escritos: Graciliano Ramos e Silviano Santiago. São Paulo: EDUSP, 1992.

TEIXEIRA, L. C. Escrita autobiográfica e construção subjetiva. Psicol. USP, v. 14, n. 1, p. 37-64, 2003.

THOMPSON, P. A voz do passado: história oral. Rio de Janeiro: Ed. Paz e Terra, 1992.

URBAN, T. Missão (quase) impossivel: aventuras e desventuras do movimento ambientalista no Brasil. São Paulo: Peirópolis, 2001.

VELHO, G. Subjetividade e sociedade: Uma experiência de geração. 2 ed. Rio de Janeiro: Jorge Zahar, 1989.

Recebido em abril de 2008. Aceito em novembro de 2009. Publicado em dezembro de 2009. 